\title{
MEMFUNGSIKAN IMAJINASI: SOSIALISASI MENULIS KREATIF MENGGUNAKAN WORDLESS BOOK PADA MURID KELAS IX DI MTS GUPPI CILEUKSA, DESA LEGOK KALER KEC. PASEH KAB. SUMEDANG
}

\author{
Sri Rosyana Ratnaningsih ${ }^{1)}$, Dian Nurrachman ${ }^{2)}$ \\ 1) Sastra Inggris,Fakultas Adab dan Humaniora, UIN Sunan Gunung Djati Bandung \\ desriyoss@gmail.com \\ 2) Sastra Inggris, Fakultas Adab dan Humaniora, UIN Sunan Gunung Djati Bandung \\ diannurrachman@gmail.com
}

\begin{abstract}
Abstrak
Menulis kreatif adalah salah satu cara murid mengembangkan ide dan imajinasinya. Akan tetapi, murid sering kali tidak dapat menemukan inspirasi untuk menulis. Wordless book sering dianggap sebagai buku yang hanya digunakan oleh anak-anak yang belum bisa membaca. sedngkan jika diteliti lebih jauh, buku tersebut dapat membantu murid yang menginjak usia remaja dalam kemampuan menulisnya. Pengabdian ini adalah suatu kegiatan sosialisasi menulis kreatif kepada murid kelas XI MTs GUPPI Cileuksa. Sosialisasi ini bertujuan untuk melatih kemampuan murid dalam menulis kreatif dengan menggunakan wordless book (buku bergambar tanpa teks). Partisipan dalam kegiatan ini adalah kelas IX A \& B MTs GUPPI Cileuksa. Hasil dari kegiatan ini menunjukkan bahwa wordless book dapat membantu mengembangkan kreatifitas dan kemampuan murid dalam menulis kreatif.
\end{abstract}

Kata kunci: menulis kreatif. Wordless Book, murid.

\begin{abstract}
Creative writing is one of the ways students develop their ideas and imagination. However, students often cannot find the inspiration to write. Wordless books are often considered books that are only used by children who cannot read. While if examined further, the book can help students who are in their teens in their writing skills. This dedication is an activity of creative writing socialization to students of class XI MTs GUPPI Cileuksa. This socialization aims to train students' ability to write creatively using wordless books. Participants in this activity are class IX A \& B MTs GUPPI Cileuksa. The results of this activity show that wordless books can help develop students' creativity and ability in creative writing.
\end{abstract}

Keyword: Creative writing, wordless book, students.

\section{PENDAHULUAN}

Buku bergambar tanpa teks (wordless book) telah lama digunakan oleh banyak pengajar terutama pada jenjang pendidikan dini seperti TK. Biasanya buku ini digunakan bagi anakanak yang belum bisa membaca. Tetapi sayangnya, buku ini tidak lagi digunakan bagi anak-anak yang sudah bisa membaca karena dianggap sudah tidak bisa memberikan manfaat yang penting.

"Many teachers look at a wordless book and decide that it is not of any use in their classroom. The fact is, teachers do not know how to successfully implement them into their curriculum, so they push them to the back and forget about them" (Marble, 2012: 8).

Ditinjau dari jenisnya, buku ini termasuk ke dalam sastra anak, meski hanya gambar visual yang disajikan. Jika didefinisikan, buku bergambar tanpa teks adalah buku yang biasanya berisi sebuah cerita tetapi tidak memiliki teks apapun untuk menunjang gambar yang disajikan. Hal ini didukung oleh pendapat Miller (1998: 376), “ $a$ 
book whose story can be understood only with the illustrations supplementing the written text". Oleh karena itu, buku bergambar tanpa teks tidak banyak digunakan sebagai media untuk belajar. Ia hanya dijadikan sebagai media untuk bercerita bagi orang tua di rumah dan tidak memiliki fungsi yang banyak bagi pengajar di sekolah.

Menurut Lewis (2001: 59) anak-anak pada kelahiran pertamanya sudah dikenalkan pada gambar-gambar. Sehingga pada dasarnya manusia memulai proses belajarnya dari gambar, apapun yang dilihatnya berupa gambar. Nodelman (2017: 2) mendukung pendapat Lewis dengan mengatakan,

"In trying to figure out how picture books work, I came upon a lot of clues in a wide range of different places: in discussions of the psychology of pictorial perception; in scholarly descriptions of how paintings, photographs, and films communicate; in theories of illustration and histories of illustrated books; and especially in analyses of the semiotics or meaningful codes of visual imagery".

Buku bergambar tanpa teks telah menjadi genre tersendiri dalam dunia sastra karena ia berdiri sebagai karya sastra. Ia tidak menggunakan teks untuk mengantarkan narasinya. Selain itu, konten yang disampaikan oleh buku ini bersifat ilustrasi dan dengannya buku ini berkomunikasi dengan pembacanya. Oleh karena itu, buku bergambar tanpa teks dapat memberikan kebebasan kepada pembaca untuk mengembangkam cerita terutama dalam penggunaan diksi. Buku ini dapat membuat pembacanya menggali perbendaharaan kata lebih dalam. Terlebih lagi bagi anak-anak atau remaja yang masih dalam tahap awal belajar Bahasa Inggris.

"In reading wordless picture books, readers are faced with a variety of visual signs. They then assign meaning to these visual signs based on their own experiences, perspectives, and the particular context of the reading event. These sign systems help readers form a type of framework that informs their interpretation of the text and helps them shape their construction of the story"
(Nodelman dalam Arif \& Hasyim, 2008: 122).

Bahasa Inggris masih dianggap sulit bagi anak-anak dan remaja meskipun mereka sudah menerima pembelajaran Bahasa Inggris sedari dini. Hal ini bisa disebabkan oleh beberapa faktor, salah satunya adalah cara belajar yang tidak menarik. Salah satu kemampuan penting dalam berbahasa adalah menulis, dan generasi muda sekarang memiliki kemampuan menulis yang buruk.

"It is no news to anybody...that today's school children as a whole are poor writers. College teachers over the country, pointing to low scores on entrance exams and poor writing samples submitted by freshmen, arestunned at the writers' inability both to express ideas clearly and to use the conventions of correctness in conveying those ideas" (Wiener dalam Carter, dkk., 1998: 9).

Kemampuan dalam menulis dapat menunjukkan kemampuan anak dalam mengembangkan ide. Ia juga dapat memperlihatkan seberapa banyak perbendaharaan kata yang dimiliki. Dengan adanya buku bergambar tanpa teks, anak-anak dapat mengembangkan ide dari ilustrasiilustrasi yang ada dalam buku.

"Many young children struggle with writing and expressing their ideas or organizing a story line. The use of wordless picture books can help a child see how a story line flows and also allows for a student's creativity and imagination to be used to create their own written script of what is occurring within the story" (Marble, 2012: 8).

Maka dari itu, penelitian ini dilakukan untuk mengembangkan kemampuan menulis kreatif anak-anak khususnya murid Sekolah Menengah Pertama (SMP). Anak-anak/remaja pada usia ini sudah mendapatkan pembelajaran Bahasa Inggris yang cukup, tetapi pada kenyataannya murid pada usia ini belum memiliki kemampuan Bahasa Inggris yang baik khususnya dalam menulis. Penulis mencoba untuk menggunakan buku bergambar tanpa teks untuk membantu murid 
mengembangkan ide atas cerita yang mereka dapatkan. Dengan adanya buku bergambar tanpa teks ini diharapkan murid dapat menjelajah dunia kosakata dalam pikirannya secara luas. Selain itu, murid akan tertantang untuk dapat mengembangkan alur cerita yang menarik.

Berdasarkan latar belakang di atas, maka masalah yang dapat diidentifikasikan dalam pengabdian ini adalah: 1) Apakah buku bergambar tanpa teks dapat membantu siswa kelas IX MTs GUPPI Cileuksa mengembangkan cerita dan memperbanyak kosakata?; 2) Dapatkah siswa kelas IX MTs GUPPI Cileuksa menyampaikan cerita yang telah mereka tulis?

\section{METODOLOGI PENGABDIAN}

Penulis melakukan pengabdian pada MTs GUPPI Cileuksa Desa Legok Kaler Kecamatan Paseh Kabupaten Sumedang. Proses sosialisasi ini diberikan khusus kepada kelas IX saja karena pada usia ini kemampuan murid seharusnya sudah baik mengingat mereka akan segera meneruskan ke jenjang pendidikan selanjutnya. Mereka akan mendapatkan kesulitan di jenjang Menengah Atas jika sekarang kemampuan mereka tidak diasah.

Buku bergambar tanpa teks yang penulis gunakan adalah buku karya Alex Latimer, dkk. yang berjudul Toast dan Springloaded karya Sam Wilson, dkk. Partisipan dalam kegiatan sosialisasi ini adalah kelas IX A dan B. Sedangkan waktu pelaksanaannya disesuaikan dengan jadwal mata pelajaran Bahasa Inggris di kelasnya. Satu kelas dibagi menjadi enam kelompok yang terdiri dari 3-4 orang. Mereka diminta untuk membuat cerita berdasarkan dengan buku yang mereka dapat. Kemudian mereka diminta untuk menyampaikan ceritanya di depan kelas secara berpasangan.

Tujuan dari pengabdian ini adalah untuk meningkatkan kemampuan menulis kreatif murid MTs GUPPI Cileuksa khususnya kelas IX. Selain itu, sosialisasi menulis kreatif ini membantu murid untuk meningkatkan kepercayaan diri dalam menyampaikan cerita di depan teman-temannya. Mereka diharapkan dapat menulis

\section{PELAKSANAAN KEGIATAN}

Kegiatan sosialisasi dimulai dengan mengadakan persetujuan dengan guru pengajar Bahasa Inggris di MTs GUPPI Cileuksa terlebih dahulu. Isi dari persetujuan tersebut adalah kesepakatan waktu pelaksanaan sosialisasi yang membutuhkan waktu 2 kali pertemuan dan kelas yang akan menjadi partisipan. Kelas IX A yang mendapatkan giliran pertama untuk kegiatan sosialisasi karena jadwal mereka jatuh pada hari Selasa dan kelas IX B hari Rabu.

Buku bergambar tanpa teks yang penulis gunakan diunduh dari internet. Proses pemilihan buku dilakukan secara acak. Dua buku terpilih dari lima buku yang telah kami unduh. Buku yang pertama adalah Springloaded karya Sam Wilson sebagai penulis, Thea Nicole de Klerk sebagai ilustrator dan Chenel Ferreira sebagai designer. Buku ini diterbitkan tahun 2016.

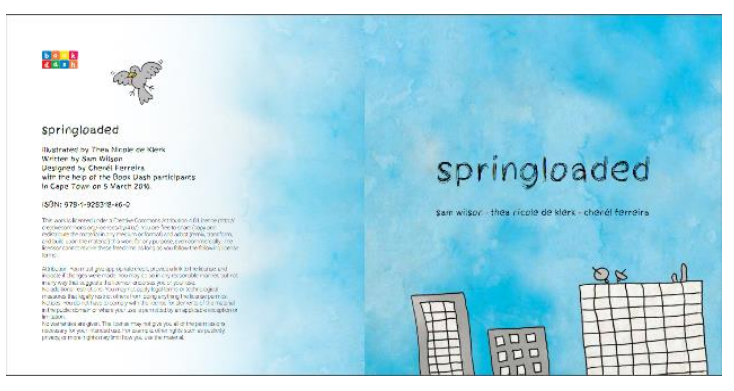

Gambar 1. Cover Buku Springloaded

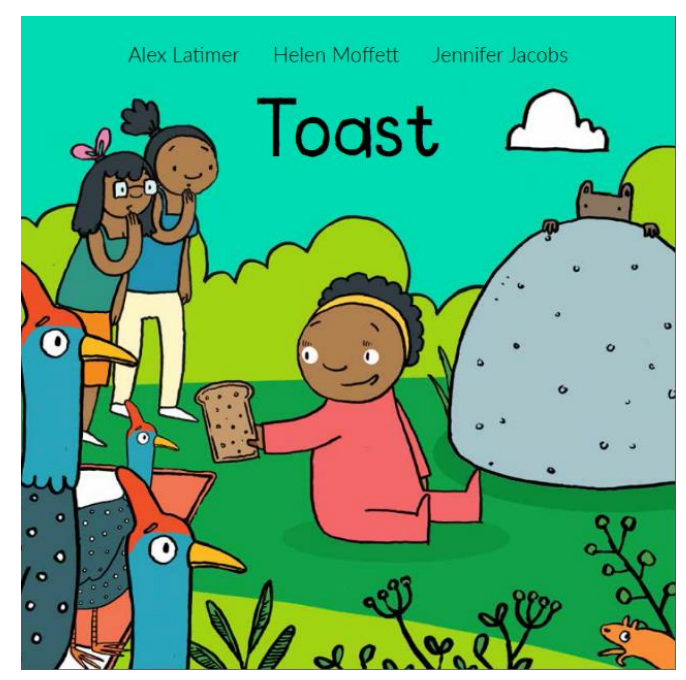

Gambar 2. Cover Buku Toast 
Buku kedua adalah Toast yang ditulis oleh Helen Moffet, Alex Latimer sebagai ilustrator dan Jennifer Jacobs sebagai designer. Diterbitkan pada tahun 2018.

Kedua buku ini dibagikan kepada setiap kelompok secara acak. Setiap kelompok diberi waktu 40 menit untuk menulis cerita sesuai dengan buku yang mereka terima. Cerita harus ditulis dalam Bahasa Inggris sehingga mereka dianjurkan untuk menggunakan kamus karena keterbatasan dalam penggunaan kata. Mereka diwajibkan untuk menulis cerita berdasarkan ilustrasi per halaman. Hal ini untuk menjaga cerita memiliki kesinambungan meskipun pada praktiknya imajinasi mereka sangat dibebaskan untuk menjelajah. Dikarenakan sosialisasi ini adalah menulis kreatif, maka murid diarahkan untuk menafsirkan setiap ilustrasi secara kreatif. Apapun kata yang muncul dalam pikiran mereka dianjurkan untuk ditulis walaupun hal itu tidak masuk akal sekalipun.

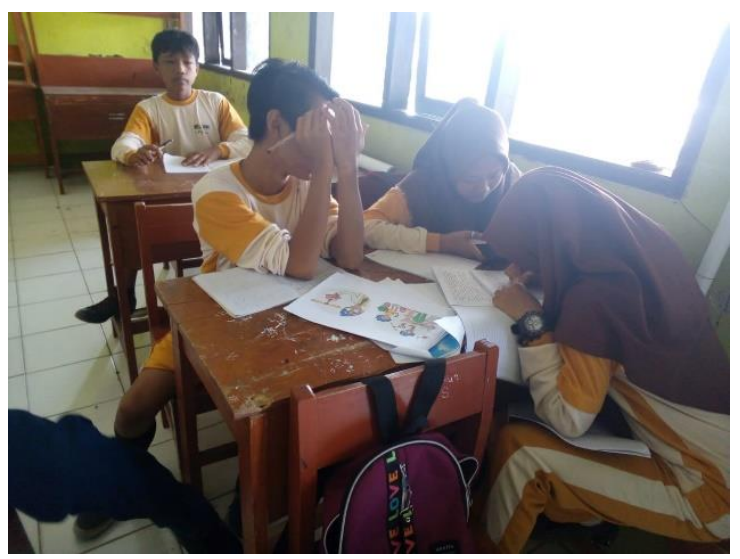

Gambar 3. Proses menulis kreatif di kelas IX A

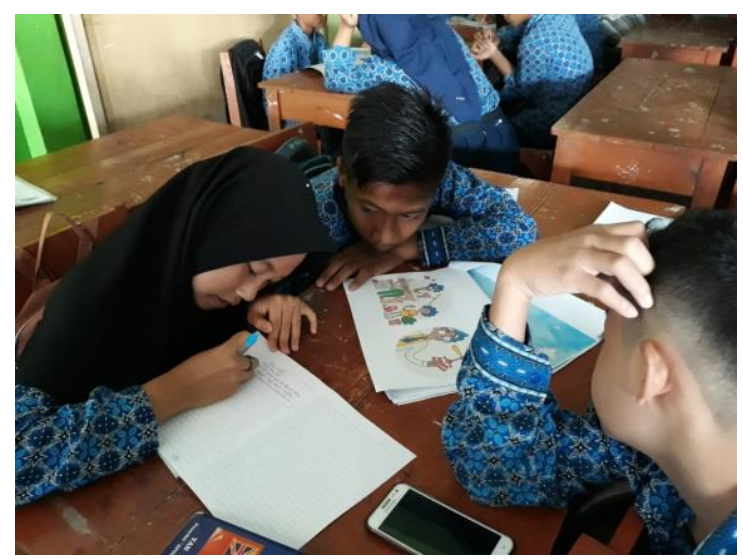

Gambar 4. Proses menulis kreatif di kelas IX B
Pada prosesnya, murid diizinkan untuk bertanya apabila ia memiliki kesulitan. terlebih dengan kurangnya perbendaharaan kata yang dimiliki. Tak jarang kesulitan mereka temui karena terkadang kamus tidak memiliki semua yang mereka butuhkan. Mereka sering menemukan kesulitan dalam mendapatkan padanan kata berkolokasi.

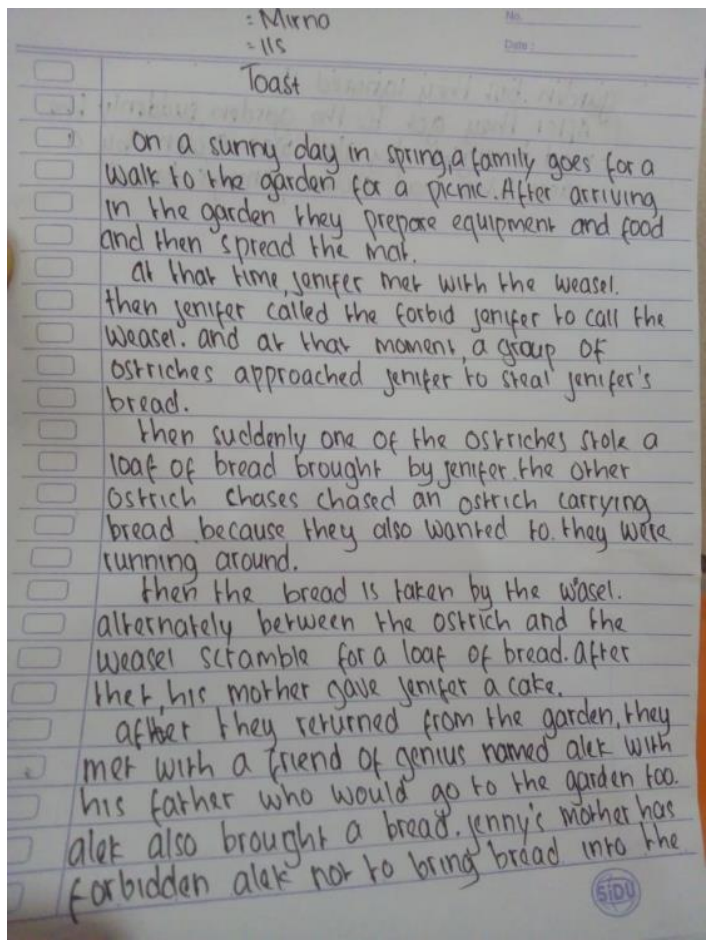

Gambar 5. Hasil menulis kreatif salah satu kelompok dari kelas IX A

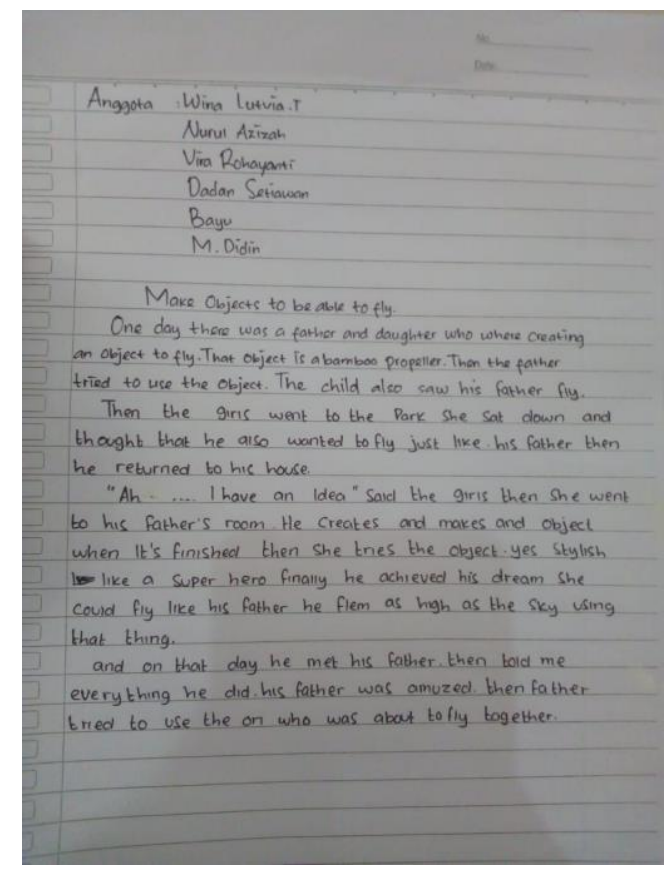

Gambar 6. Hasil menulis kreatif salah satu kelompok dari kelas IX B 
Mereka diminta untuk menulis karangan mereka pada kertas terpisah untuk memudahkan penulis memeriksa hasil kerjanya. Gambar 5 dan Gambar 6 adalah beberapa hasil menulis kreatif mereka.

Proses selanjutnya dari sosialisasi ini adalah membacakan cerita yang telah ditulis di depan kelas. Setiap kelompok diwajibkan untuk memiliki perwakilan sebanyak dua orang.

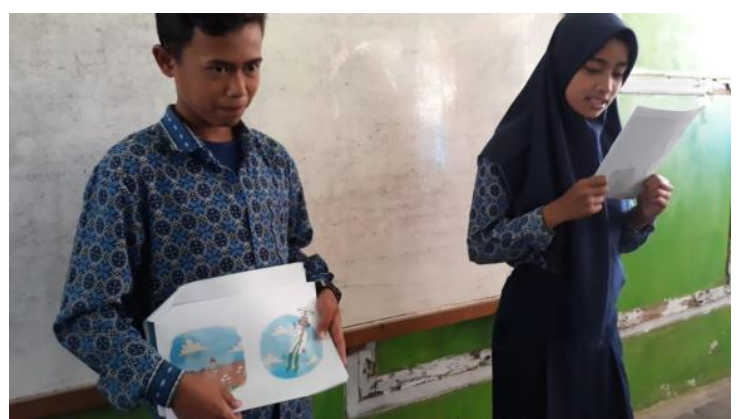

Gambar 7. Proses bercerita di kelas IX A

Satu orang untuk bercerita dan sisanya bertugas untuk menunjukkan bagian mana ( dalam buku bergambar tanpa teks) yang sedang diceritakan. Mereka wajib bercerita dengan menggunakan suara yang lantang.

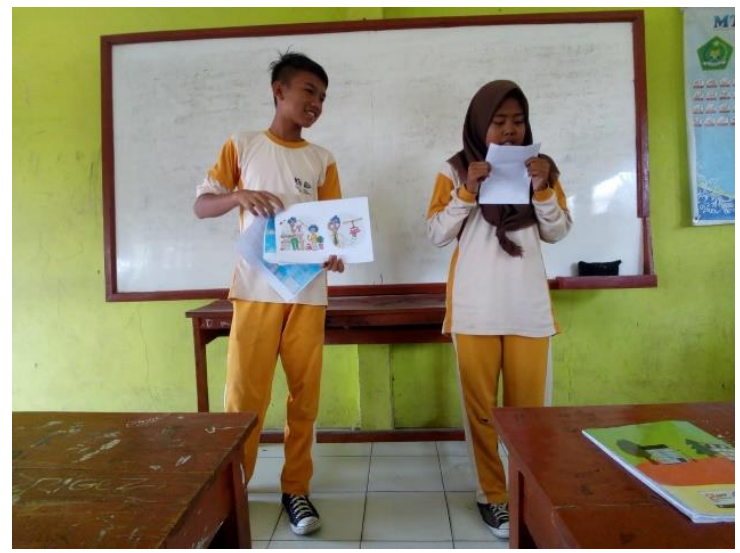

Gambar 8. Proses bercerita di kelas IX B

Sayangnya, murid-murid kelas IX ini masih belum bisa bercerita secara bebas tanpa harus perlu melihat pada tulisannya. Meskipun mereka sudah diberikan waktu seminggu untuk dapat menghafal cerita masing-masing. Sehingga proses bercerita dirasa tidak efektif.

\section{HASIL DAN PEMBAHASAN}

Atas proses yang telah dilaksanakan dan hasil menulis kreatif yang telah didapatkan, berikut beberapa pembahasan yang dapat penulis temukan:

\section{Kemampuan untuk Mengembangkan Alur Cerita}

Proses pembacaan terhadap buku bergambar tanpa teks dapat membantu murid untuk mengembangkan alur cerita. Ilustrasi yang terdapat dalam buku membantu murid kelas IX MTs GUPPI Cileuksa membangun cerita yang berkesinambungan. Mereka dapat membuat cerita lengkap dari pengenalan (eksposisi) sampai ke penyelesaian. Hal ini karena murid mengaplikasikan hasil pembacaannya terhadap teks. Seperti yang sudah ditulis oleh Golden \& Gerber (dalam Crawford \& Hade, 2000 : 69), "their work shows how visual cues powerfully affect the ways in which readers construct meaning, regarding the story narrative".

\section{Kemampuan Mengembangkan Topik dan Konsep Narasi}

Dengan adanya buku ini murid dapat mendapatkan topik menulis dengan mudah. Hal ini dikarenakan mereka terbantu untuk membuat batasan topik yang diangkat dengan ilustrasi yang ada. Selain itu, murid terbantu dalam menentukan konsep cerita yang diinginkan. Tak seperti kebanyakan kelompok, satu atau dua kelompok membuat narasi dalam bentuk dialog. "However, often wordless picture books are overlooked by teachers to help young children develop their literacy concepts" (Marble, 2012: 13).

\section{Kemampuan untuk Mengembangkan Kalimat dan Perbendaharaan Kata}

Pada saat proses menulis kreatif, banyak murid yang menanyakan benda atau hal apa yang ada dalam ilustrasi. Salah satunya adalah mereka tidak mengetahui bahwa hewan yang ada pada cerita Toast adalah musang dan kalkun. Sehingga ketidaktahuan ini membuat mereka akhirnya mengetahui bahasa Inggris dari hewan-hewan tersebut. Hal ini sangat berguna dalam menambahkan perbendaharaan kata mereka. 
Selain itu, mereka terpacu untuk dapat mengembangkan kalimat. Dengan bertambahnya kosakata baru, kalimat mereka pun menjadi kaya akan padanan kata yang selaras untuk mengimbangi cerita.

\section{Kemampuan dalam Mengembangkan Kreatifitas}

Ilustrasi-ilustrasi dalam kedua buku termasuk ke dalam hal-hal yang bisa ditemui oleh murid dalam kehidupan sehari-hari. Tetapi ada beberapa objek yang tidak dapat mereka temukan dalam aktivitas sehari-hari. Salah satu objek tersebut terdapat dalam buku Springloaded, yaitu baling-baling yang membuat karakter dalam buku dapat terbang. Dengan ini, murid secara kreatif menamai baling-baling tersebut sebagai baling-baling bambu (bamboo propeller). Ia beralasan bahwa baling-baling dalam buku mengingatkannya pada film animasi dari Jepang berjudul Doraemon. "Good readers do not read in a vacuum rather they bring their prior knowledge and experiences to bear on their reading" (Rosenblatt dalam Arif \& Hashim, 2008: 123).

Selain itu, tidak adanya teks dalam buku membuat mereka secara bebas menamai setiap tokoh yang ada dalam buku. Hal ini membuat narasi dalam kedua buku tersebut kaya akan penokohan karena beberapa kelompok mendapatkan buku yang berjudul sama.

\section{PENUTUP}

\section{Kesimpulan}

Menulis adalah salah satu jembatan bagi seseorang untuk dapat menyampaikan ide atau isi pikirannya. oleh karena itu menulis adalah salah satu keterampilan yang harus dimiliki oleh murid terutama bagi mereka yang akan memasuki jenjang pendidikan yang lebih tinggi. Salah satunya adalah kemampuan dalam menulis kreatif. Murid akan dapat mengembangkan imajinasi mereka melewati menulis kreatif. Sayangnya, kurangnya latihan membuat murid tidak tahu cara menjelajahi imajinasi mereka sendiri.

Wordless Book (buku bergambat tanpa teks) dapat membantu murid untuk mengembangkan kemampuan menulis mereka.
Ilustrasi dalam buku-buku tersebut dapat membantu murid dalam mengembangkan kemampuan mereka bercerita, yaitu mengembangkan alur, konsep dan topik. Selain itu, kreatifitas mereka pun terasah diiringi terpakainya pengetahuan mereka akan suatu hal yang sering mereka temui di kehidupan sehari-hari. Mengingat kegiatan ini adalah menulis kreatif dalam bahasa Inggris, murid terbantu untuk menambah kosakata baru akibat hal-hal yang baru mereka ketahui dari buku. Meskipun begitu, buku ini belum bisa meningkatkan rasa percaya diri murid untuk bercerita di depan kelas. Hal ini dikarenakan proses menulis dilakukan dalam bahasa Inggris yang pada dasarnya sudah dianggap sulit oleh murid.

\section{Saran}

Atas kesimpulan yang sudah didapat, akan lebih baik jika menulis kreatif dijadikan latihan rutin. Potensi yang dimiliki murid kelas IX MTs GUPPI Cileuksa cukup memadai dan jika dilatih terus-menerus maka menulis bukan lagi hal yang sulit bagi mereka. Selain itu, kemampuan bahasa Inggris mereka pun akan meningkat seiring dengan bertambahnya perbendaharaan kata mereka.

\section{DAFTAR PUSTAKA}

Arif, Marina Mohd. \& Fatimah Hashim. 2008. Reading from the Wordless: A case Study on the Use of Wordless Picture Books. CCSE Journal (English Language Teaching) Vol 1, No.1, 121-128. Tersedia pada: https://www.researchgate.net/publication/42 386330_Reading from the Wordless A_C ase Study on the Use of Wordless Pictur e Books [Diakses di Cilegon, Indonesia: 15 September 2019].

Marble, Shannon. 2012. How Do Wordless Picture Books Help Develop Writing For All Students? Thesis. St. John Fisher College: Fisher Digital Publications. Tersedia pada: https://www.google.com/url?sa=t\&rct=j\&q= \&esrc $=$ s $\&$ source $=w e b \& c d=3 \&$ ved $=2$ ahUK EwjnaSs19jkAhWV XMBHbBkCf0QFjACegQI AxAC\&url=https\%3A\%2F\%2Fcore.ac.uk\% 2Fdownload\%2Fpdf\%2F48616716.pdf\&usg =AOvVaw1SauMoDDaa70w4j4na1h6c [Diakses di Cilegon, Indonesia: 16 September 2019]. 
Miller, T. 1998. The place of picture books in middle-level classroom. Journal of Adolescent \& Adult Literacy, 41(5), 376381.

Lewis, D. 2001. Reading contemporary picture books: Picturing Text. London: Routledge.

Nodelman, Perry. Naomi Hamer \& Mavis Reimer. 2017. More Words about Pictures: Current Research on Picture Books and Visual/Verbal Texts for Young People. New York: Routledge.

Carter, Patricia A. dkk. 1998. Improving Student Writing Skills Using Wordless Picture Books. Saint xavier University.

Crawford, Patricia A. \& Daniel D. Hade. 2000. Inside the Picture, Outside the Frame: Semiotics and the Reading of Wordless Picture Books. Journal of Research in Childhood Education. Vol. 15, No.1. Tersedia pada: https://www.researchgate.net/publication/24 8909228 Inside the Picture Outside the F rame Semiotics and the Reading of Wor dless_Picture Books [Diakses di Cilegon, Indonesia: 16 September 2019]. 